\title{
Investigation of the Atterberg limits and undrained fall-cone shear strength variation with water content of some peat soils
}

\author{
P. J. Vardanega ${ }^{a *}$, C. L. Hickey ${ }^{\mathrm{b}, \mathrm{c}}$, K. Lau ${ }^{\mathrm{b}}$, H. D. L. Sarzier ${ }^{\mathrm{b}}$, C. M. Couturier ${ }^{\mathrm{b}}$, G. Martin $^{\mathrm{a}}$ \\ ${ }^{a}$ Department of Civil Engineering, University of Bristol, Bristol, United Kingdom \\ ${ }^{\mathrm{b}}$ Formerly, Department of Civil Engineering, University of Bristol, Bristol, United Kingdom \\ ${ }^{\mathrm{c}}$ Civil engineer, Arup, London, United Kingdom
}

Received 8 August 2018; received in revised form 13 November 2018; accepted 18 November 2018

\begin{abstract}
Road construction in peatlands is challenging. The ability to make rapid estimates of the response of construction soils derived from natural peats to changes in water content is useful for pavement and geotechnical engineers. This paper details some laboratory test results on peat soils sourced from two sites in the South-west of England. The samples were sieved and the roots and natural fibres removed prior to laboratory testing. Water contents on the natural specimens were determined. The percentage of roots in the samples was determined. The thread rolling test was used to estimate the plastic limit of the peat soil material. A series of fall cone tests were conducted at varying moisture contents to determine the liquid limit of the peat soil as well as study the variation of fall cone undrained shear strength with the liquidity index, logarithmic liquidity index and the water content ratio. Both the liquidity index and logarithmic liquidity index are able to predict the fall cone undrained strength to within $\pm 40 \%$ around $90 \%$ of the time. When using the water content ratio to predict the fall cone undrained shear strength an accuracy of $\pm 40 \%$ is achieved around $85 \%$ of the time. The study concludes that the liquidity index and logarithmic liquidity index are better predictors of fall cone undrained shear strength but the water content ratio approach may be preferred if the engineer is less confident in plastic limit determination for peat soils.
\end{abstract}

Keywords: Peats; Fall cone testing; Atterberg limits; Undrained strength; Liquidity index

\section{Introduction}

Road construction in peat areas is very difficult due to the high settlement potential of peat deposits [1]. According to Spedding [2] peat “... is invariably found with significant moisture content at the surface of the ground, within a depth of between 2 and 15 meters." Peat soils exhibit low values of undrained shear strength in natural conditions $[3,4]$. Natural peats contain very high water content, “...low strength, high compressibility and high shrinkage on drying" [1]. Various studies detailing construction challenges in such deposits have been published [5-8]. Edil [3,9,10] has reviewed construction over peat materials - focusing on the compressibility characteristics of the material. The review paper by O'Kelly and Pichan discussed the decomposition and

\footnotetext{
$\bar{*}$ Corresponding author

E-mail addresses: p.j.vardanega@bristol.ac.uk (P. J. Vardanega); Claire.Hickey@arup.com (C. L. Hickey); kaikyology@gmail.com (K. Lau); helena.sarzier@laposte.net (H. D. L. Sarzier); chloe.couturier@outlook.fr (C. M. Couturier); gary.martin@bristol.ac.uk (G. Martin)

Peer review under responsibility of Chinese Society of Pavement Engineering.
}

compressibility characteristics of peat soils and concluded that "uncontrolled or unexpected decomposition in fibrous peat deposits may cause significant additional settlement of bearing strata, adversely impacting on the performance of engineering structures founded on or within such deposits" [11]. Nie et al [12] also studied the influence of organic content on decomposition and concluded that for the Chinese peats in their study organic content had a major influence on the mechanical properties. Use of peat as a lightweight fill material for construction purposes is assisted by the fact that upon drying ".... an irreversible change takes place in the colloidal fractions and the peat will 'take-up' only a small fraction of the water it originally contained on being immersed again" [1]. This investigation aims (in part) to see the potential variations in undrained shear strength due to variations of water content (w). This paper aims to: (a) Compare the measured Atterberg limits and loss on ignition (LOI) for peat soils from two locations in the South-West of England to those for some other English peat soils - reported in the literature [13-14] and (b) Determine the undrained shear strength variation with increasing water content for the peat soils studied and compare the results to previously published studies [15-18]. A summary of the sample collection, preparation and testing details is given in Section 3 of this paper (for further details see the dissertations of Hickey [19], Lau [20] and Sarzier and Couturier [21]). 


\section{Background}

\subsection{Plastic Limit $\left(w_{P}\right)$}

O'Kelly [22] has criticised the use of Atterberg limits for peat soils, the major reasons being the presence of fibres and the variability of the test results. Skempton and Petley [13] stated "The plastic limit cannot be readily determined, even with the highly humidified peats, and the test is undoubtedly subject to personal variations". However, the thread rolling test remains an important test and arguably the only way to determine the brittle transition point [23] and will therefore, be retained in this study. The challenges of determining the $w_{P}$ are clear when the soil fibres are included in the sample. This study focuses on the soil component of the peat material, where the thread rolling test is easier to perform.

\subsection{Liquid Limit $\left(w_{L}\right)$}

The definition of the liquid limit as the water content of $20 \mathrm{~mm}$ penetration of a 30 degree, $80 \mathrm{~g}$ cone was proposed in Sherwood and Ryley [24] and subsequently adopted into the British Standard BS1377-1975 [25]. O'Kelly et al. [26] recently published a review of the use of fall cones to determine the Atterberg limits of finegrained soils, concluding in part, that the fall cone should be adopted universally to determine the liquid limit.

\subsection{Undrained strength at the liquid limit}

Based on a review of previously published data-sets, Wroth and Wood [15] adopted an undrained shear strength at $w_{L}\left(c_{L}\right)$ of 1.7 $\mathrm{kPa}$. Nagaraj et al [27] also reviewed the ranges of undrained shear strength measured at the liquid limit from different publications with different methods of $c_{u}$ determination arguing that a wide range exists in the reported literature and that a unique strength should not be assigned to $c_{L}$. In discussion of [27], Haigh and Vardanega [28] argued ascribing an undrained strength at $w_{L}$ is valid as the fall cone test is essentially a strength measurement and if $w_{L}$ is to be assigned to a particular fall cone penetration, then an undrained strength can be associated with it. The fall cone test can be used to estimate undrained shear strength. Hansbo [29] gave the following Equation which can be used to back-analyse fall-cone tests and estimate undrained shear strength $\left(c_{u}\right)$ :

$c_{u}=K\left(\frac{m g}{d^{2}}\right)$

where, $K=$ the cone factor; $m=$ fall cone mass, $g=$ gravitational acceleration and $d=$ fall cone penetration. When using the British standard cone [30] which has a mass of $80 \mathrm{~g}$ and a cone angle of 30 degrees as well as assuming that the $c_{u}$ at $20 \mathrm{~mm}$ penetration (liquid limit) is equal to $1.7 \mathrm{kPa}$ a $K$ value of 0.867 is calculated. A theoretical value of 1.33 for the cone factor (semi-rough condition) was given by Koumoto and Houlsby for a 30 degree cone [31]. Wood [32] explored the effect of changing cone angle on the cone factor. Brown and Huxley [33] reviewed the cone factor for the $30^{\circ}$ cone in more detail and showed slightly lower cone factors than 0.867 for the BSI cone as they took $c_{L}=1.5 \mathrm{kPa}$. $K=0.867$ is used in this paper and therefore for the analysis presented in this work a $c_{L}$ of $1.7 \mathrm{kPa}$ is assumed throughout. It must be noted that the values of fall-cone undrained shear strength $\left(c_{u, F C}\right)$ quoted in this work are as accurate as the assumed value of $1.7 \mathrm{kPa}$ at the liquid limit [16].

\subsection{Variation of $c_{u}$ with changes in $w$}

Many researchers have related changes in undrained shear strength to changes in liquidity index $\left(I_{L}\right)[15-18,34]$, which is computed by Eq. (2):

$I_{L}=\frac{w-w_{p}}{w_{L}-w_{p}}$

Wroth and Wood [15] gave an equation of the form:

$c_{u}=100 c_{L} \exp \left(-4.6 I_{L}\right)$

Eq. (3) implies a strength variation of 100 from $w_{L}$ to $w_{P}$ (an assumption made in Schofield and Wroth [35], based on examination of data from Skempton and Northey [36], an assumption that was used in [15] and [37]). Wood [34,38] gives a more general form of Eq. (3) which can be written as:

$c_{u}=c_{L} R_{M W}^{\left(1-I_{L}\right)}$

where, $R_{M W}=$ the computed factor increase in $c_{u}$ as the $w$ decreases from $w_{L}$ to $w_{P}$.

Koumoto and Houlsby [31] advocated the use of logarithmic liquidity index $\left(I_{L N}\right)$ (Eq. (5)) when modelling the change of undrained shear strength with changes in water content:

$I_{L N}=\frac{\ln \left(\frac{w}{w_{p}}\right)}{\ln \left(\frac{w_{L}}{w_{p}}\right)}$

Koumoto and Houlsby [31] showed that Eq. (6) matched the data for six fine grained materials reasonably well. Eq. (6) retains the factor 100 strength increase assumed in [15] but introduces the $I_{L N}$ concept. Eq. (6) gives as strength of $1.38 \mathrm{kPa}$ at liquid limit: Koumoto and Houlsby [31] were using a $60 \mathrm{~g}, 60^{\circ}$ cone.

$I_{L N}=1.070-0.217 \ln \left(c_{u}\right)$

Vardanega and Haigh [16] compiled a large database of 101 soils (641 fall cone measurements, all taken using the BSI cone) and after performing regression analysis produced two equations of the form suggested in Wood [34], Eqs. (7) and (8). Eqs. (7) and (8) link undrained shear strength (back-analysed from the fall cone) to $I_{L}$ and $I_{L N}$ respectively:

$c_{u, F C}=c_{L} 34.3^{\left(1-I_{L}\right)}$

where, $\mathrm{c}_{\mathrm{L}}=1.7 \mathrm{kPa}$ and $0.2<\mathrm{I}_{\mathrm{L}}<1.1$

$c_{u, F C}=c_{L} 83.5^{\left(1-I_{L N}\right)}$

where, $\mathrm{c}_{\mathrm{L}}=1.7 \mathrm{kPa}$ and $0.2<\mathrm{I}_{\mathrm{LN}}<1.1$

Kuriakose et al. [17] advocated the use of water content ratio $\left(w / w_{L}\right.$ ) (or the void ratio $(e)$ normalised with the void ratio at $w_{L}$ $\left.\left(e_{L}\right)\right)$ to predict the undrained shear strength. Earlier studies have also shown the benefits of the $\left(w / w_{L} ; e / e_{L}\right)$ ratio when studying aspects of soil behaviour [39,40,41,42]. Regression relationships linking changes in $c_{u}$ to changes in $w / w_{L}$ has been reported in various publications [43,44,45,46]. Vardanega and Haigh [18], when discussing Kuriakose et al. [17], re-analysed the same database presented in Vardanega and Haigh [16] and reported the following regression Equation:

$\log _{10}\left(c_{u, F C}\right)=2.662-2.432\left[\frac{w}{w_{L}}\right]$

Vardanega and Haigh [18] did note that the coefficient of determination calculated for Eq. (9) was lower than that obtained when using $I_{L}$ or $I_{L N}$ as the predictor of $c_{u, F C}$ [16]. 


\section{Material and methods}

\subsection{Sample Collection}

The 'Exmoor peats' were sourced from the Exmoor National Park near the town of Dulverton in Squallacombe (site 1) and Blackpitts (site 2). At the Exmoor sites, the superficial grassed surface was removed and the samples were taken from a depth of approximately $100 \mathrm{~mm}$ and placed in plastic bags. The 'Glastonbury peats' were sourced from the RSPB Ham Wall Nature Reserve in Glastonbury. At the Glastonbury site, samples were collected from two locations about $100 \mathrm{~m}$ apart at a depth of approximately $200 \mathrm{~mm}$.

\subsection{Sample Preparation}

The samples were brought back to the Geomechanics Laboratory at the University of Bristol having been sealed in plastic bags on site. Several moisture contents were measured from each bag (results summarised in Table 1). Free water was not used as part of the moisture content testing at this stage. In accordance with BS 1377 [30], a portion of the peat sample from each bag was weighed and put in a bucket with de-ionised water added which was then mixed until the roots and organic fines were separated out. The material was then washed through a $0.425 \mathrm{~mm}$ sieve into another bucket - material retained in the sieve was oven dried until constant mass was achieved to determine the mass (percentage) of roots (see Table 1). Material that passed through the $0.425 \mathrm{~mm}$ sieve was allowed to settle in the bucket until supernatant water appeared which was then poured off. The residual sludge was then transferred into trays and oven dried at approximately $50^{\circ} \mathrm{C}$ with the aim of achieving a water content co-incident with a $15 \mathrm{~mm}$ fall cone drop (modified from BS 1377, Part 2, 1990: clause 4.2.4.8, [30]). In some cases, a hand drier was used to further dry the sample prior to initial fall cone testing. When penetrations were sought lower than $15 \mathrm{~mm}$ the hand drier was also used during sample preparation. After fall-cone testing water contents were determined using an oven drying temperature of about $105^{\circ} \mathrm{C}$ as per BSI (1990).

\subsection{Laboratory Testing}

The Atterberg limits $[47,48]$ were determined in accordance with
BSI [30] using the remoulded material that had had the roots and other material removed by sieving using the $0.425 \mathrm{~mm}$ sieve (as described in the previous section).

\subsubsection{Fall Cone Liquid Limit}

The liquid limits were determined using (BSI [30]) using the standard British Cone $\left(80 \mathrm{~g}, 30\right.$ degrees with the $w_{L}$ corresponding to the water content at $20 \mathrm{~mm}$ penetration). Previous research by Kodikara et al. [49] and Feng [50, 51] advocated the use of power law functions to describe the variation of water content $(w)$ with fall cone penetration $(d)$ over the more traditional semi-logarithmic formulations [15]. For the data-set analysed in this paper, little variation in the computed values of $w_{L}$ between the semi-log and power law approaches was observed. The $w_{L}$ values shown in Table 1 and used in this study were determined using the regression function generated from fitting $\ln (w)$ to $\ln (d)$ (power relationship) and using this to derive the water content at $20 \mathrm{~mm}$ penetration. In addition to fall cone penetrations taken about the liquid limit, penetrations on drier samples were taken so as to capture the undrained strength increase with the concomitant decrease in water content. Table 2 shows the full set of fall cone penetrations which range from 4.97 to $26.45 \mathrm{~mm}(n=126)$.

A summary of the measured fall cone test data is given in Table 2 , note that some tests were conducted at penetrations less than 16 $\mathrm{mm}$ (generally not used in $w_{L}$ determination) to estimate undrained strengths closer to the $w_{P}$. The $c_{u}$ calculated using Eq. (1) range from about $1 \mathrm{kPa}$ to $27.5 \mathrm{kPa}$ with an average value of $3.8 \mathrm{kPa}$. While these values are derived from back-analysis of remoulded, sieved peat soil this range does compare well with that given by Moayedi and Nazir [4] in a recent review paper who suggested a range of $c_{u}$ of 3 to $17 \mathrm{kPa}$ for peat materials. Edil [3] stated a range of $c_{u}$ values for peats in natural conditions of between 5 and 20 $\mathrm{kPa}$. While the fall-cone undrained shear strength values reported in this paper are for the soil component only the range of values are comparable with those quoted in both $[3,4]$. Therefore, the relationships derived in this paper may prove useful for geotechnical engineers wishing to make estimates of undrained shear strength and its variation as water content changes.

\subsubsection{Thread Rolling Plastic Limit}

The $w_{P}$ is a very useful soil mechanics test as it determines the brittle transition point of the material [23]. The plastic limit test

Table 1

Summary index test data (a) water content $(w)$ and Atterberg limits $\left(w_{L}\right.$ and $\left.w_{P}\right)$ and (b) loss on ignition.

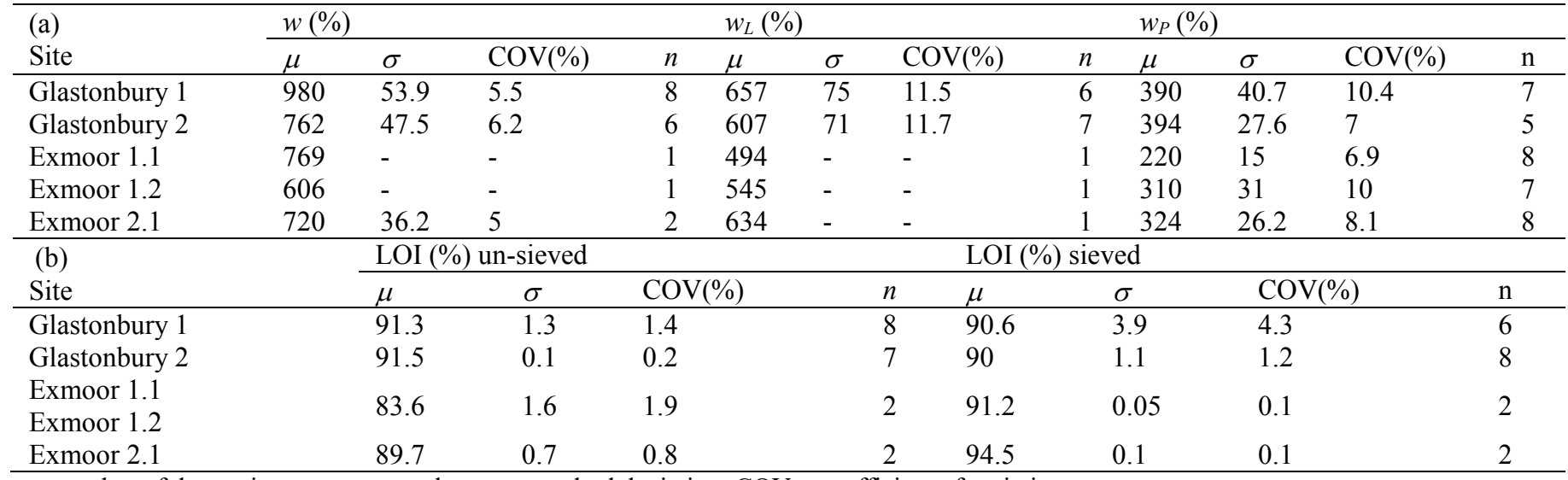

$\mathrm{n}=$ number of data points; $\mu=$ mean value; $\sigma=$ standard deviation; $\mathrm{COV}=$ coefficient of variation 
Table 2

Fall cone test data.

\begin{tabular}{|c|c|c|c|c|c|c|c|c|c|c|c|}
\hline No. & Test Series & $\begin{array}{l}d \\
(\mathrm{~mm})\end{array}$ & $\begin{array}{l}w \\
(\%)\end{array}$ & No. & Test Series & $\begin{array}{l}d \\
(\mathrm{~mm})\end{array}$ & $\begin{array}{l}w \\
(\%)\end{array}$ & No. & Test Series & $\begin{array}{l}d \\
(\mathrm{~mm})\end{array}$ & $\begin{array}{l}w \\
(\%)\end{array}$ \\
\hline 1 & \multirow[t]{5}{*}{ Glastonbury 1.1} & 16.57 & 626 & 43 & \multirow{5}{*}{ Glastonbury 2.1} & 18.34 & 755 & 85 & & 15.33 & 521 \\
\hline 2 & & 19.85 & 658 & 44 & & 19.62 & 773 & 86 & & 16.88 & 538 \\
\hline 3 & & 17.96 & 640 & 45 & & 19.68 & 681 & 87 & & 18.33 & 553 \\
\hline 4 & & 21.45 & 673 & 46 & & 17.13 & 666 & 88 & & 19.74 & 567 \\
\hline 5 & & 22.14 & 682 & 47 & & 18 & 667 & 89 & Glastonbury 2.6 & 6.26 & 422 \\
\hline 6 & \multirow[t]{5}{*}{ Glastonbury 1.2} & 16.8 & 675 & 48 & & 20.86 & 689 & 90 & & 8.37 & 437 \\
\hline 7 & & 16 & 668 & 49 & & 21.28 & 695 & 91 & & 8.58 & 432 \\
\hline 8 & & 17.79 & 683 & 50 & Glastonbury 2.2 & 16.25 & 598 & 92 & & 7.77 & 436 \\
\hline 9 & & 19.02 & 685 & 51 & & 16.56 & 595 & 93 & & 9.23 & 447 \\
\hline 10 & & 20.29 & 695 & 52 & & 17.69 & 606 & 94 & & 9.98 & 448 \\
\hline 11 & \multirow[t]{5}{*}{ Glastonbury 1.3} & 18.1 & 670 & 53 & & 19.44 & 615 & 95 & & 10.94 & 458 \\
\hline 12 & & 19.25 & 672 & 54 & & 21.41 & 625 & 96 & & 10.19 & 457 \\
\hline 13 & & 18.59 & 671 & 55 & Glastonbury 2.3 & 16.09 & 593 & 97 & & 11.33 & 463 \\
\hline 14 & & 22.77 & 676 & 56 & & 16.54 & 595 & 98 & & 12.2 & 474 \\
\hline 15 & & 21.2 & 674 & 57 & & 19.05 & 608 & 99 & & 13.63 & 483 \\
\hline 16 & \multirow[t]{13}{*}{ Glastonbury 1.4} & 11.64 & 571 & 58 & & 19.71 & 609 & 100 & & 14.44 & 489 \\
\hline 17 & & 11.43 & 570 & 59 & & 20.81 & 616 & 101 & & 15.81 & 507 \\
\hline 18 & & 12.79 & 573 & 60 & Glastonbury 2.4 & 10.26 & 481 & 102 & & 16.84 & 518 \\
\hline 19 & & 13.5 & 581 & 61 & & 10.32 & 482 & 103 & & 19.03 & 545 \\
\hline 20 & & 14.11 & 584 & 62 & & 10.81 & 509 & 104 & Glastonbury 2.7 & 21.22 & 766 \\
\hline 21 & & 15.32 & 589 & 63 & & 11.24 & 507 & 105 & & 16.67 & 686 \\
\hline 22 & & 15.09 & 583 & 64 & & 11.46 & 511 & 106 & & 15.72 & 683 \\
\hline 23 & & 15.91 & 593 & 65 & & 11.92 & 502 & 107 & & 17.01 & 624 \\
\hline 24 & & 16.61 & 595 & 66 & & 12.15 & 500 & 108 & & 4.97 & 463 \\
\hline 25 & & 17.88 & 606 & 67 & & 12.63 & 492 & 109 & & 14.87 & 636 \\
\hline 26 & & 19.4 & 618 & 68 & & 13.49 & 498 & 110 & & 14.62 & 637 \\
\hline 27 & & 22.56 & 636 & 69 & & 13.9 & 509 & 111 & & 11.01 & 560 \\
\hline 28 & & 21.79 & 636 & 70 & & 14.35 & 517 & 112 & Exmoor 1.1 & 15.05 & 459 \\
\hline 29 & \multirow{10}{*}{ Glastonbury 1.5} & 8.13 & 475 & 71 & Glastonbury 2.5 & 11.29 & 487 & 113 & & 18.75 & 476 \\
\hline 30 & & 8.96 & 481 & 72 & & 11.28 & 490 & 114 & & 22 & 500 \\
\hline 31 & & 8.58 & 477 & 73 & & 12.61 & 501 & 115 & & 23.6 & 529 \\
\hline 32 & & 10.95 & 493 & 74 & & 11.27 & 486 & 116 & Exmoor 1.2 & 14.3 & 488 \\
\hline 33 & & 11.5 & 496 & 75 & & 13.09 & 506 & 117 & & 17.2 & 502 \\
\hline 34 & & 12.32 & 501 & 76 & & 11.82 & 491 & 118 & & 17.85 & 519 \\
\hline 35 & & 13.03 & 503 & 77 & & 12.2 & 495 & 119 & & 20.1 & 541 \\
\hline 36 & & 13.28 & 505 & 78 & & 11.09 & 485 & 120 & & 22 & 570 \\
\hline 37 & & 13.72 & 512 & 79 & & 13.08 & 502 & 121 & & 23.7 & 589 \\
\hline 38 & & 14.56 & 515 & 80 & & 13.72 & 509 & 122 & Exmoor 2.1 & 14.7 & 565 \\
\hline 39 & \multirow[t]{4}{*}{ Glastonbury 1.6} & 9.5 & 509 & 81 & & 14.08 & 513 & 123 & & 16.75 & 599 \\
\hline 40 & & 17.46 & 687 & 82 & & 15.03 & 521 & 124 & & 19 & 609 \\
\hline 41 & & 16.1 & 637 & 83 & & 15.15 & 524 & 125 & & 22.9 & 667 \\
\hline 42 & & 11.56 & 586 & 84 & & 14.67 & 517 & 126 & & 26.45 & 712 \\
\hline \multicolumn{12}{|c|}{ Data summary } \\
\hline \multicolumn{2}{|c|}{$\mathrm{n}$} & 126 & 126 & & & & & & & & \\
\hline \multicolumn{2}{|l|}{$\max$} & 26.45 & 773.5 & & & & & & & & \\
\hline \multicolumn{2}{|l|}{$\mu$} & 15.5 & 565.5 & & & & & & & & \\
\hline \multicolumn{2}{|l|}{$\min$} & 4.97 & 422.4 & & & & & & & & \\
\hline \multicolumn{2}{|l|}{$\sigma$} & 4.2 & 82.8 & & & & & & & & \\
\hline \multicolumn{2}{|c|}{$\mathrm{COV}=\sigma / \mu(\%)$} & 27.3 & 14.6 & & & & & & & & \\
\hline
\end{tabular}

is criticised as being crude as it is not a mechanised test. However, the thread-rolling test was reported to be repeatable to $\pm 3 \%$ by Sherwood and Ryley [24] when performing a benchmarking study across many laboratories in the United Kingdom. As previously mentioned, it is reported to be a difficult test to perform on peat soils $[13,14]$. However, it must be stated that a unique value of undrained shear strength should not be assigned at the $w_{P}$ $[23,27,52]$. Table 3 shows the individual results of the thread- 


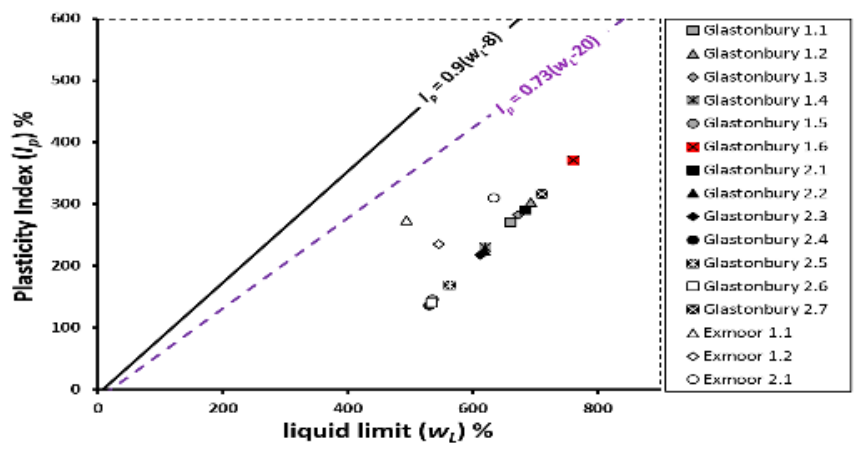

Fig. 1. Casagrande chart $[53,54]$ showing the new data collected during this study.

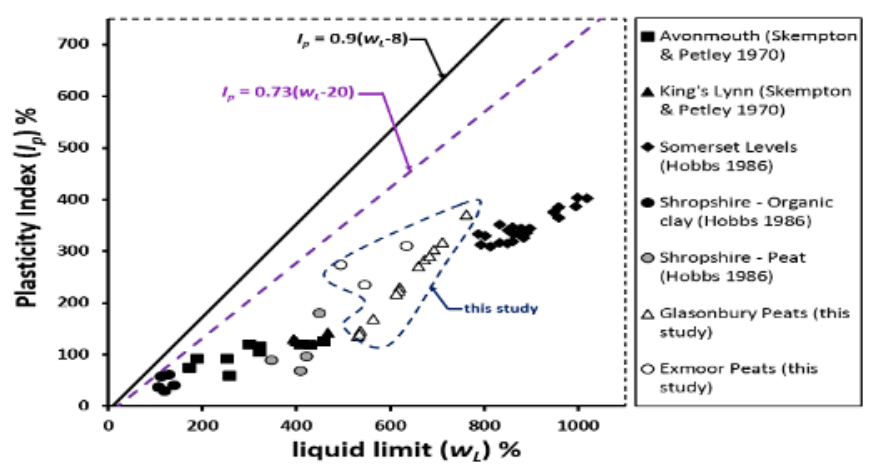

Fig. 2. Data collected in this study compared with data from some other UK peats (Avonmouth and King's Lynn data from Skempton and Petley [13]; Shropshire Data digitised from Figure 18 in Hobbs [14] where Hobbs cites Soil Mechanics Ltd 1983 as the original source of the data; Somerset Levels Data also digitised from Figure 18 in Hobbs [14] where Hobbs cites Petley 1983 (pers. comm.) as the original source of the data).

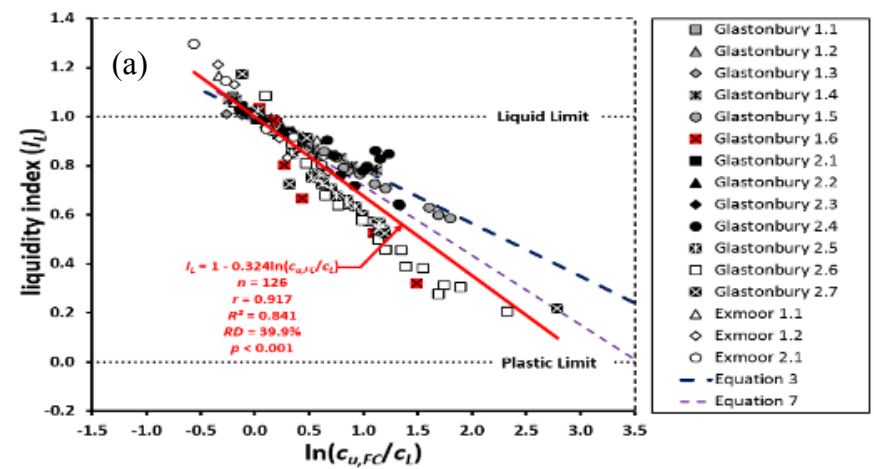

(b)

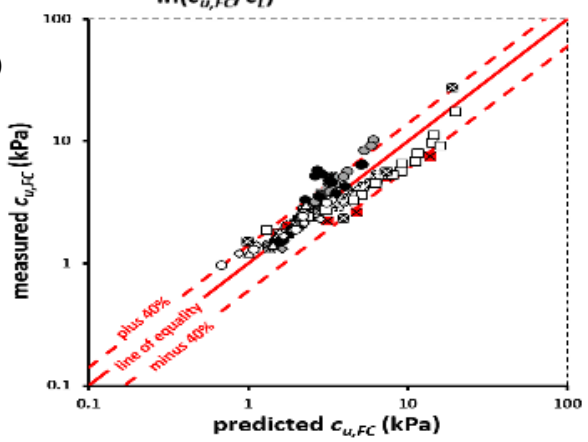

Fig. 3. (a) Plot of $I_{L}$ versus natural logarithm of normalised fall cone undrained shear strength $\ln \left(c_{u, F C} / c_{L}\right)$ and (b) Measured $c_{u, F C}$ versus predicted $c_{u, F C}$ plot (using Eq. (11)).
Table 3

Individual thread rolling test results.

\begin{tabular}{llll}
\hline Site & $w_{P}(\%)$ & Site & $w_{P}(\%)$ \\
\hline Glastonbury 1 & 344 & Exmoor 1.1 & 213 \\
& 328 & & 199 \\
& 394 & Exmoor 1.2 & 303 \\
& 431 & & 352 \\
& 385 & & 348 \\
& 432 & & 315 \\
Glastonbury 2 & 413 & & 264 \\
& 345 & & 295 \\
& 410 & & 297 \\
& 404 & & 344 \\
Exmoor 1.1 & 404 & & 352 \\
& 406 & & 318 \\
& 241 & & 306 \\
& 230 & & 355 \\
& 220 & & 333 \\
& 224 & & 280 \\
& 231 & & \\
\hline
\end{tabular}

rolling testing carried out for the sites used in this study. The average values of $w_{P}$ from Table 1 are used in the subsequent analyses presented in this paper.

\subsection{Classification using the Casagrande Approach}

Fig. 1 shows the peat soil materials in this study $(n=16)$ plotted on the Casagrande-style chart [53]. The Equations of the A-line and U-lines are also shown (Eq. (10)) [54]. (Some recent research suggests that the relationship between the plasticity index $\left(I_{p}\right)$ and $w_{L}$ is non-linear, [55]). Fig. 2 shows the data shown on Fig. 1 compared with the results from other studies from peat soils from the UK.

$$
\begin{aligned}
& I_{P}(\%)=0.73\left(w_{L}-20\right) \\
& I_{P}(\%)=0.9\left(w_{L}-8\right)
\end{aligned}
$$

\subsection{Loss on Ignition}

LOI was determined in accordance [56]. The summary results from this testing are also given in Table 1 . The LOI values are above $80 \%$ and are higher than that reported by [13] for the Avonmouth (range 26.1 to $74.7 \%$ ), and King's Lynn (range 74.2 to $82.0 \%$ ) peat soils.

\section{Results}

\subsection{Correlation of normalized $c_{u}$ with $I_{L}$}

The regression shown in Fig. 3(a) is given as Eq. (11) with the relevant statistical measures given in square brackets:

$I_{L}=1-0.324 \ln \left(c_{u, F C} / c_{L}\right)$

$\left[n=126, r=0.917, R^{2}=0.841, R D=39.9 \%, p<0.001\right]$

where $r=$ correlation coefficient; $R^{2}=$ coefficient of determination; $R D=$ relative deviation (defined in [57]) and $p=\mathrm{p}$-value.

Eq. (11) was adjusted so that the $c_{u}$ at $I_{L}=1.0$ corresponds to 1.7 $\mathrm{kPa}$, the loss of $R^{2}$ when this condition is imposed is observed in 
the third decimal. Eq. (11) can be rearranged as Eq. (12)

$\frac{c_{u, F C}}{c_{L}} \approx 21.9^{\left(1-I_{L}\right)} \quad 0.2<\mathrm{I}_{\mathrm{L}}<1.2$
where $\mathrm{c}_{\mathrm{L}}=1.7 \mathrm{kPa}$

The computed value of $R_{M W} \approx 22$, is lower than the value reported in Vardanega and Haigh [16] for clays and silts (cf. Eq. (7) in this paper). The $R_{M W}$ value is dependent on the accurate determination of the $w_{P}$ which is a challenge for natural peat soils but is reasonable to determine $w_{P}$ for the soil component of said soils. It is recommended to use Eq. (12) in the range $0.2<I_{L}<1.2$ as this is the approximate range of data available. Additionally, the $R_{M W}$ value in Eq. (12) is lower than the commonly used value of 100 $[15,34,35]$. Examination of Fig. 3(b) shows that most of the data fits within $\pm 40 \%$ prediction bounds (i.e. 112 out of 126 data-points or $89 \%$ ) which are a similar level of accuracy to that obtained using the database of Vardanega and Haigh $( \pm 50 \%)[16]$.

\subsection{Correlation of normalised $c_{u}$ with $I_{L N}$}

The regression shown in Fig. 4(a) is given as Eq. (13) with the relevant statistical measures given in square brackets:

$I_{L N}=1-0.292 \ln \left(c_{u, F C} / c_{L}\right)$

$\left[n=126, r=0.917, R^{2}=0.840, R D=40.0 \%, p<0.001\right]$

Eq. (13) has been adjusted so that the $c_{u}$ at $I_{L N}=1.0$ corresponds to $1.7 \mathrm{kPa}$, the loss of $R^{2}$ when this condition is imposed is observed in the third decimal. Eq. (13) can be expressed as Eq. (14):

$\frac{c_{u, F C}}{c_{L}} \approx 30.7^{\left(1-I_{L N}\right)}$

$0.2<\mathrm{I}_{\mathrm{LN}}<1.2$

where $c_{\mathrm{L}}=1.7 \mathrm{kPa}$

The computed value of $R_{M W} \approx 31$ is lower than the value computed using the database of Vardanega and Haigh [16] of 83.5 (cf. Eq. (8) in this paper). As with Eq. (12), it is recommended to use Eq. (14) in the range $0.2<I_{L}<1.2$ as this is the approximate range of data available. Examination of Fig. 4(b) shows that most of the data also fits within $\pm 40 \%$ prediction bounds (i.e. 113 out of 126 data-points or $90 \%$ ) which are a similar level of accuracy to that obtained using the database in Vardanega and Haigh $( \pm 50 \%)$ [16].

\subsection{Correlation of normalised $c_{u}$ with $w / w_{L}$}

The regression shown on Fig. 5(a) is given as Eq. (15) with the relevant statistical measures given in square brackets:

$\frac{w}{w_{L}}=1-0.102 \ln \left(c_{u, F C} / c_{L}\right)$

$\left[n=126, r=0.857, R^{2}=0.734, R D=51.6 \%, p<0.001\right]$

Eq. (15) has been adjusted so that the $c_{u}$ at $w / w_{L}=1.0$ corresponds to $1.7 \mathrm{kPa}$, the loss of $R^{2}$ when this condition is imposed is observed in the third decimal. Examination of Fig. 5(b) shows that most of the data also fits within $\pm 40 \%$ prediction bounds (i.e. 107 out of 126 data-points or $85 \%$ ) which is a similar level of accuracy reported for the database in Vardanega and Haigh [16] $( \pm 50 \%)$, but the quality of fit is not as good as those seen in Figs. 3(b) and 4(b): note the lower $R^{2}$ value and the increased dispersion of the data $[17,18]$. However, Eq. (15) does not require the determination of the thread rolling plastic limit and therefore may be a more useful way to model changes with the water content of natural peats.
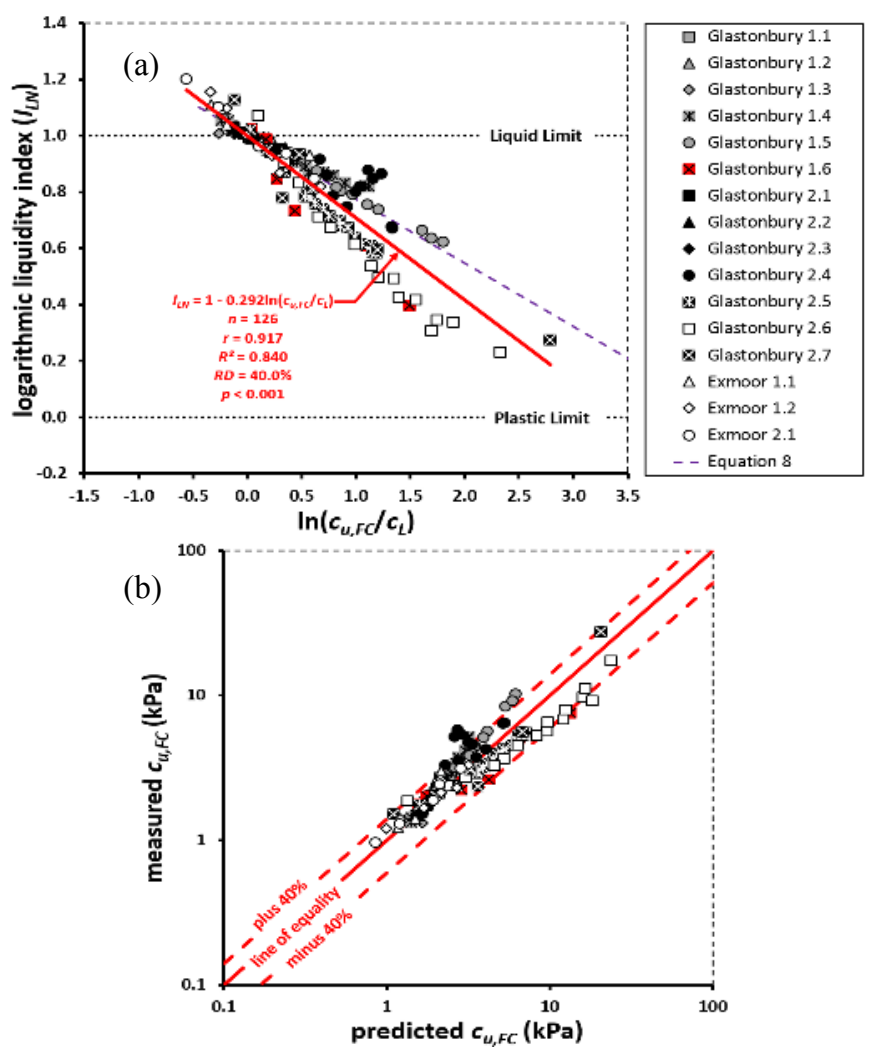

Fig. 4. (a) Plot of $I_{L N}$ versus natural logarithm of normalised fall cone undrained shear strength $\ln \left(c_{u, F C} / c_{L}\right)$ and (b) Measured $c_{u, F C}$ versus predicted $c_{u, F C}$ plot (using Eq. (13)).
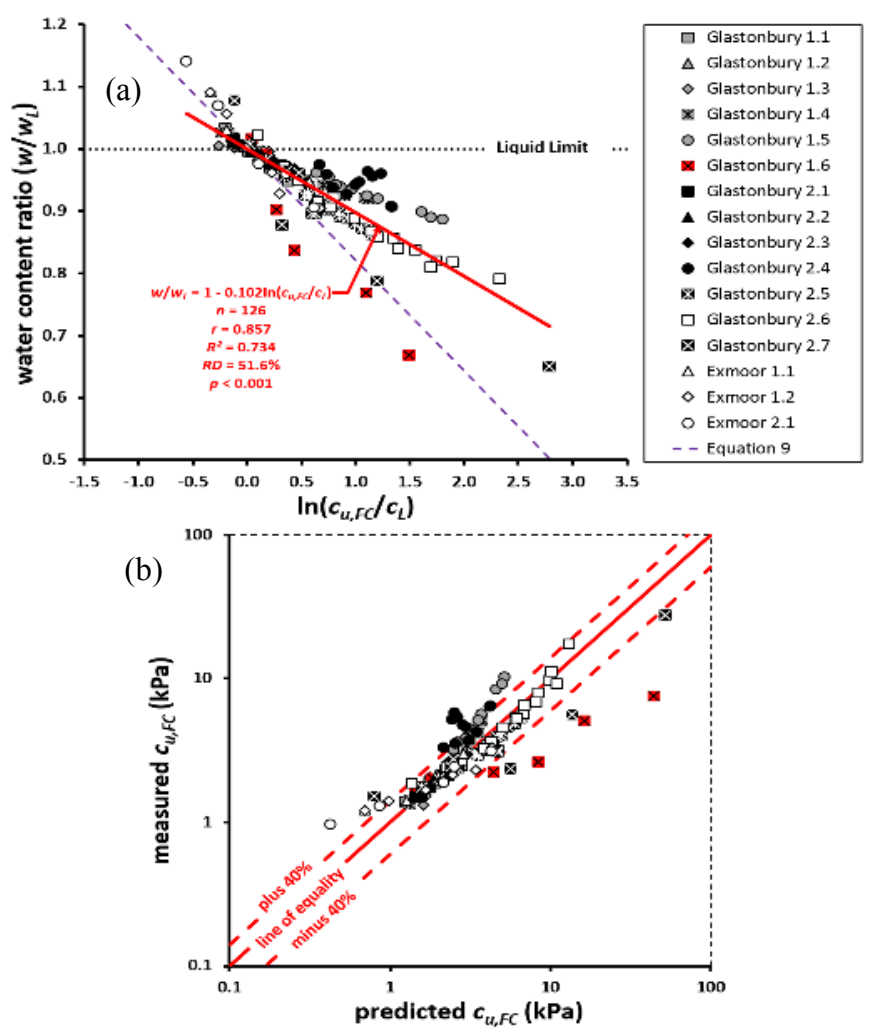

Fig. 5. (a) Plot of $w / w_{L}$ versus natural logarithm of normalised fall cone undrained shear strength $\ln \left(c_{u}, F C / c_{L}\right)$ and (b) Measured $c_{u, F C}$ versus predicted $c_{u, F C}$ plot (using Eq. (15)). 


\section{Discussion and conclusions}

The advantage of using the $I_{L}$ (or $I_{L N}$ ) is that an $R_{M W}$ value can be calculated. $R_{M W}$ is a useful parameter for engineers as it allows approximation of the rate of decrease of undrained shear strength that may be expected as water content increases for peat soils. However, it does require the determination of the $w_{P}$. If the $w_{P}$ cannot be determined to acceptable accuracy when characterising a peat deposit then the $w / w_{L}$ is also good predictor of undrained shear strength. However, the engineer using a correlation between undrained shear strength and $w / w_{L}$ must accept that the proximity to the brittle transition (which is defined by the thread rolling test not a specific strength) will not be captured [18].

This paper has presented the results of some laboratory characterisation of two English peat soils, focussing on the soil index properties and the variation of $c_{u, F C}$ with changing $I_{L}$ or $w / w_{L}$. The following concluding points are made:

1. By examination of the Casagrande chart, the Atterberg limits obtained for the tested peat soils fit within the bounds suggested by previous testing on English peat soils (although the degree of scatter is high);

2. The LOI for these soils is high compared with historical data from Avonmouth and King's Lynn;

3. The $R_{M W}$ value for the data-set presented in this paper was computed to be about 22 when the $I_{L}$ is correlated with normalised $c_{u, F C}$ and 31 when the $I_{L N}$ is correlated with normalised $c_{u, F C}$. It is reiterated that these computed values are dependent on the successful measurement of the $w_{P}-\mathrm{a}$ measurement that is difficult, even for these sieved peats. For the peat soils studied in this paper the $R_{M W}$ values are lower than the average value computed by Vardanega and Haigh [16] using a large database of measurements of clays and silts;

4. The $w / w_{L}$ was able to predict the $c_{u, F C}$ variation to $\pm 40 \%$ $85 \%$ of the time which is not as accurate as using the $I_{L}$ (or $I_{L N}$ ) which are accurate to $\pm 40 \% 89 \%$ and $90 \%$ of the time respectively. However, the use of $w / w_{L}$ may be a more appropriate method to capture the undrained shear strength variation of natural peat soils with changing water content.

\section{Acknowledgements}

The second and third authors would like to thank S. Hughes, the site manager at the Ham Wall Nature Reserve, for permitting excavation of peat samples from this site. The fourth and fifth authors thank M. Angus for helping them collect the peat samples in the Exmoor National Park.

\section{References}

[1] J. O. Tresidder, A Review of Existing Methods of Road Construction Over Peat. Road Research Technical Paper No. 40. Department of Scientific and Industrial Research Road Research Laboratory, Her Majesty's Stationery Office, 1958.

[2] P. J. Spedding, Peat. Fuel, 67 (7) (1988) 883-900.

[3] T. B. Edil, Construction over peats and organic soils. In: Proceedings of Conference on Recent Advances in Soft Soil Engineering, Kuching, Sarawak, Malaysia, 1 1997 85-108.

[4] H. Moayedi, R. Nazir, Malaysian Experiences of Peat Stabilization, State of the Art. Geotechnical and
Geological Engineering, 36 (1) (2018) 1-11.

[5] E. T. Hanrahan, An Investigation of Some Physical Properties of Peat. Géotechnique, 4 (3) (1954) 108-123.

[6] E. T. Hanrahan, A road failure on peat. Géotechnique, 14 (3) (1964) 185-202.

[7] L. Casagrande, Construction of embankments across peaty soils. Journal of Boston Society of Civil Engineers, 53 (3) (1966) 272-317.

[8] N. Boylan, P. Jennings, M. Long, Peat slope failure in Ireland. Quarterly Journal of Engineering Geology and Hydrogeology, 41 (1) (2008) 93-108.

[9] T. B. Edil, Recent advances in geotechnical characterization and construction over peats and organic soils. In: Proceedings of the Second Conference on Advances in Soft Soil Engineering and Technology, Putrajaya, Malaysia, 2003 3-26.

[10] T. B. Edil, Recent advances in construction over soft ground including peat. In: Proceedings of the Soft Soils 2016 Conference, Bandung, Indonesia, 2016.

[11] B. C. O'Kelly, S. P. Pichan, Effects of decomposition on the compressibility of fibrous peat - A review. Geomechanics and Geoengineering, 8 (4) (2013) 286-296.

[12] L. Nie, Y. Lv, M. Li, Influence of organic content and degree of decomposition on the engineering properties of a peat soil in NE China. Quarterly Journal of Engineering Geology and Hydrogeology, 45 (4) (2012) 435-446.

[13] A. W. Skempton, D. J. Petley, Ignition loss and other properties of peats and clays from Avonmouth, King's Lynn and Cranberry Moss. Géotechnique, 20 (4) (1970) 343-356.

[14] N. B. Hobbs, Mire morphology and the properties and behaviour of some British and foreign peats. Quarterly Journal of Engineering Geology, 19 (1) (1986) 7-80.

[15] C. P. Wroth, D. M. Wood, The correlation of index properties with some basic engineering properties. Canadian Geotechnical Journal, 15 (2) (1978) 137-145.

[16] P. J. Vardanega, S. K. Haigh, The undrained strength liquidity index relationship. Canadian Geotechnical Journal, 51 (9) (2014) 1073-1086.

[17] B. Kuriakose, B. M. Abraham, A. Sridharan, B. T. Jose, Water content ratio: an effective substitute for liquidity index for prediction of shear strength of clays. Geotechnical and Geological Engineering, 35 (4) (2017) 1577-1586.

[18] P. J. Vardanega, S. K. Haigh, Discussion of "Water Content Ratio: An Effective Substitute for Liquidity Index for Prediction of Shear Strength of Clays" by Beshy Kuriakose, Benny Mathews Abraham, A. Sridharan \& Babu T. Jose. Geotechnical and Geological Engineering, 35 (6) (2017) 3039-3044.

[19] C. H. Hickey, Some Fall Cone Testing on English Peats. Undergraduate Research Report No. 1617RP031. Department of Civil Engineering, University of Bristol, Bristol, U.K., 2017.

[20] K. Y. Lau, Investigative Laboratory Characterisation of some English Peats. Individual Research Project Report. Department of Mechanical Engineering, University of Bristol, Bristol, U.K., 2017.

[21] H. D. L. Sarzier, C. M. Couturier, A characterisation study of an English peat. Undergraduate Research Report No. 1516RP024. Department of Civil Engineering, University of Bristol, Bristol, U.K., 2016.

[22] B. C. O'Kelly, Atterberg limits are not appropriate for peat soils. Geotechnical Research, 2 (3) (2015) 123-134. 
[23] Haigh, S. K., Vardanega, P. J. and Bolton, M. D. The plastic limit of clays. Géotechnique, 63 (6) (2013) 435-440.

[24] P. T. Sherwood, M. D. Ryley, An investigation of a conepenetrometer method for the determination of liquid limit. Géotechnique, 20 (2) (1970) 203-208.

[25] D. M. Wood, Cone penetrometer and liquid limit. Géotechnique, 32 (2) (1982) 152-157.

[26] B. C. O'Kelly, P. J. Vardanega, S. K. Haigh, Use of fall cones to determine Atterberg limits: a review. Géotechnique, 68 (10) (2018) 843-856, Corrigendum, 935.

[27] H. B. Nagaraj, A. Sridharan, H. M. Mallikarjuna, Reexamination of Undrained Strength at Atterberg Limits Water Contents. Geotechnical and Geological Engineering, 30 (4) (2012) 727-736.

[28] S. K. Haigh, P. J. Vardanega, Discussion of "ReExamination of Undrained Strength at Atterberg Limits Water Contents" by H.B. Nagaraj, A. Sridharan and H.M. Mallikarjuna. Geotechnical and Geological Engineering, 30 (6) (2012) 1389-1391.

[29] S. Hansbo, A new approach to the determination of shear strength of clay by the fall cone test. Proceedings of the Royal Swedish Geotechnical Institute, 14 (1957) 5-47.

[30] British Standards Institute (BSI) BS 1377-2. Methods for test of soils for civil engineering purposes: Classification tests. British Standards Institute, London, United Kingdom, 1990.

[31] T. Koumoto, G. T. Houlsby, Theory and practice of the fall cone test. Géotechnique, 51 (8) (2001) 701-712.

[32] D. M. Wood, Some fall-cone tests. Géotechnique, 35 (1) (1985) 64-68.

[33] P. J. Brown, M. A. Huxley, The cone factor for a $30^{\circ}$ cone. Ground Engineering, 29 (10) (1996) 34-36.

[34] D. M. Wood, Soil behaviour and critical state soil mechanics. Cambridge University Press, UK., 1990.

[35] A. N. Schofield, C. P. Wroth, Critical State Soil Mechanics. McGraw-Hill, UK., 1968.

[36] A. Skempton, R. Northey, The sensitivity of clays. Géotechnique, 3 (1) (1952) 30-53.

[37] B. Sharma, P. K. Bora, Plastic Limit, Liquid Limit and Undrained Shear Strength of Soil - Reappraisal. Journal of Geotechnical and Geoenvironmental Engineering, 129 (8) (2003) 774-777.

[38] D. M. Wood, Discussion: "Cone penetrometer and liquid limit", Géotechnique, 33 (1) (1983) 79-80.

[39] T. S. Nagaraj, M. S. Jayadeva, Re-examination of one point methods of liquid limit determination. Géotechnique, 31 (3) (1981) 413-425.

[40] T. S. Nagaraj, B. R. S. Murthy, Rationalisation of Skempton's compressibility equation. Géotechnique, 33 (4) (1983) 433-444.

[41] T. S. Nagaraj, B. R. Srinivasa Murthy, A critical reappraisal of the compression index equation. Géotechnique, 36 (1) (1986) 27-32.

[42] F. J. Griffiths, R. C. Joshi, Identification of cementation in overconsolidated clays. Géotechnique, 38 (3) (1988) $451-452$.
[43] A. Federico, Relationships $\left(c_{u}-w\right)$ and $\left(c_{u}-\delta\right)$ for remoulded clayey soils at high water content. Rivista Italiana di Geotecnica, 17 (1) (1983) 38-41.

[44] A. Federico, A comment on undrained residual strength. Rivista Italiana di Geotecnica, 17 (3) (1983) 164-166.

[45] L. T. Lee, Predicting geotechnical parameters for dredged materials using the slump test method and index property correlations. DOER Technical Notes Collection (ERDC TNDOER-D-X), U.S. Army Engineer Research and Development Center, Vicksburg, Mississippi, USA., 2004.

[46] S. A. Berilgen, H. Kiliç, K. Özaydin, Determination of undrained shear strength for dredged golden horn marine clay with laboratory tests. Proceedings of the Sri Lankan geotechnical society's first international conference on soil $\&$ rock engineering, August 5-11, Colombo, Sri Lanka, 2007.

[47] A. Atterberg, Lerornas forhållande till vatten, deras plasticitetsgränser och plasticitetsgrader. Kungliga Lantbruksakademiens Handlingar och Tidskrift, 50 (2) (1911) 132-158 (In Swedish).

[48] A. Atterberg, Die Plastizität der Tone. Internationale Mitteilungen der Bodenkunde, 1 (1911) 4-37 (In German).

[49] J. Kodikara, Seneviratne, H. N. and Wjyakulasooriya, C. V. Evaluation of plastic limit and plasticity index by Cone Penetrometer. Proceedings of the Asian Regional Symposium on Geotechnical Problems and Practices in Foundation Engineering, Colombo, Sri Lanka, 11986 117121.

[50] T-W. Feng, Fall-cone penetration and water content relationship of clays. Géotechnique, 50 (2) (2000) 181-187.

[51] $\mathrm{T}-\mathrm{W}$. Feng, A linear $\log \mathrm{d}-\log \mathrm{w}$ model for the determination of consistency limits of soils. Canadian Geotechnical Journal, 38 (6) (2001) 1335-1342.

[52] K. Prakash, Discussion of "Plastic Limit, Liquid Limit, and Undrained Shear Strength of Soil - Reappraisal" by Binu Sharma and Padma K. Bora. Journal of Geotechnical and Geoenvironmental Engineering, 131 (3) (2005) 403.

[53] A. Casagrande, Classification and identification of soils. Proceedings of the American Society of Civil Engineers, 73 (6) (1947) 783-810.

[54] A. K. Howard, The revised ASTM standard on the Unified Classification System. Geotechnical Testing Journal, 7 (4) (1984) 216-222.

[55] Y. M. Reznik, A Brief Note on Nonlinear Relationship Between Liquid Limits and Plasticity Indices of Soils. Geotechnical and Geological Engineering, 35 (6) (2017) 3035-3038.

[56] British Standards Institute (BSI) BS 1377-3. Methods for test of soils for civil engineering purposes: Chemical and electrochemical tests. British Standards Institute, London, United Kingdom, 1990.

[57] T. J. Waters, P. J. Vardanega, Re-examination of the coefficient of determination (r2) using road materials engineering case studies. Road and Transport Research, 18 (3) (2009) 3-12. 